\title{
KORELASI PENGUASAAN KOSAKATA DENGAN KETERAMPILAN MENULIS EKSPOSISI SISWA KELAS XI SMA NEGERI 03 KOTA BENGKULU
}

\author{
Wenny Aulia Sari ${ }^{\bowtie}$ \\ ${ }^{1}$ Institut Agama Islam Negeri (IAIN) Bengkulu \\ 1auliasariwenny@,gmail.com
}

\begin{abstract}
This study aims to obtain a description of vocabulary mastery, exposition writing ability, and vocabulary mastery correlation with exposition writing skills of class XI students of State High School 03 Kota Bengkulu. Type of quantitative research with descriptive method. The population in this study were 333 people spread in six classes. The sample of this study was class XI with a total of 42 people. The research data was obtained through objective tests for mastery of vocabulary and performance tests for exposition writing skills. The results of the study and data analysis of vocabulary mastery correlation with exposition writing skills as follows. First, the mastery of the words of class XI of the State High School 03 City of Bengkulu is in the qualification of almost 54.09. Second, the ability to write exposition of class XI students of class XI of SMA Negeri 03 Kota Bengkulu is in a qualification almost enough with a value of 54.88. Third, there is a significant correlation between vocabulary mastery and exposition writing skills of class XI students of SMA Negeri 03 Kota Bengkulu.
\end{abstract}

Keywords: vocabulary mastery; writing skills;descriptive method;exposition

Abstrak : Penelitian ini bertujuan untuk memperoleh hasil deskripsi penguasaan kosakata, kemampuan menulis eksposisi, dan korelasi penguasaan kosakata dengan keterampilan menulis eksposisi siswa kelas XI SMA Negeri 03 Kota Bengkulu. Jenis penelitian kuantitatif dengan metode deskriptif. Populasi dalam penelitian ini adalah 333 orang yang tersebar dalam enam kelas. Sampel penelitian ini adalah kelas XI dengan jumlah 42 orang. Data penelitian ini diperoleh melalui tes objektif untuk penguasaan kosakata dan tes unjuk kerja untuk kemampuan menulis eksposisi. Hasil penelitian dan analisis data korelasi penguasaan kosakata dengan keterampilan menulis eksposisi sebagai berikut. Pertama, Penguasaan koasakata siswa kelas XI SMA Negeri 03 Kota Bengkulu berada pada kualifikasi hampir cukup dengan nilai 54,09. Kedua, kemampuan menulis eksposisi siswa kelas XI siswa kelas XI SMA Negeri 03 Kota Bengkulu berada pada kualifikasi hampir cukup dengan nilai 54,88. Ketiga, terdapat korelasi yang signifikan antara penguasaan kosakata dengan keterampilan menulis eksposisi siswa kelas XI SMA Negeri 03 Kota Bengkulu. .

Kata Kunci : penguasaan kosa kata; keterampilan menulis; eksposisi; metode deskriptif 


\section{Pendahuluan}

Pembelajaran Bahasa dan Sastra Indonesia pada dasarnya adalah pembelajaran keterampilan berbahasa. Pembelajaran bahasa Indonesia bertujuan meningkatkan kemampuan intelektual, emosional, sosial, dan mampu meningkatkan pengetahuan serta kemampuan berbahasa. Untuk mencapai tujuan tersebut, dapat dilakukan dengan kegiatan menulis. Keterampilan menulis merupakan salah satu keterampilan yang harus dikuasai oleh siswa, karena menulis merupakan salah satu keterampilan berbahasa yang berperan penting dalam meningkatkan kemampuan intelektual siswa.

Dengan adanya keterampilan menulis, siswa mampu mengungkapkan gagasan dan pemikirannya dalam suatu kerangka berpikir yang logis dan sistematis. Selain itu, keterampilan menulis juga dapat membantu siswa untuk berpikir secara kritis. Dengan demikian, penulis harus terampil memanfaatkan morfologi, struktur bahasa, dan kosakata. Salah satu bentuk tulisan itu adalah menulis eksposisi yang ada di dalam Standar Isi Kurikulum Tingkat Satuan Pendidikan Mata Pelajaran Bahasa Indonesia.

Keterampilan menulis eksposisi tidak bisa diabaikan karena memiliki peranan penting dalam proses belajar mengajar (PBM) dan merupakan tuntutan dari kurikulum yang harus dipelajari, dikuasi dan dikaji oleh siswa di sekolah-sekolah. Eksposisi merupakan tulisan yang memamaparkan atau menjabarkan suatu objek atau permasalahn untuk memberikan informasi kepada pembaca dengan tidak mempengaruhi pikiran pembaca. Ekposisi tersusun atas kalimat-kalimat yang mengandung informasi jelas mengenai suatu hal.

Berdasarkan hasil wawancara informal dengan salah seorang guru Bahasa Indonesia di SMA Negeri 03 Kota Bengkulu, pembelajaran menulis eksposisi belum mencapai hasil yang maksimal. Rendahnya kemampuan menulis eksposisi siswa dikarenakan siswa kurang mampu menuangkan ide atau gagasan ke dalam tulisan, siswa kurang menguasi kosakata. Selain itu, siswa tidak memahami tentang tulisan eksposisi. Hal itu terlihat dari rendahnya hasil tes menulis eksposisi siswa. Kemampuan siswa dalam menulis khususnya menulis eksposisi hanya berkisar antara $45 \%$ sampai $60 \%$. Dengan kata lain, keterampilan menulis siswa masih di bawah KKM yang ditetapkan (75\%).

Keterampilan menulis membutuhkan, penguasaan dan pemahaman terhadap kosakata yang cukup. Tarigan mengatakan kualitas keterampilan berbahasa jelas tergantung kepada kuantitas dan kualitas kosakata yang dimilikinya. Semakin kaya kosakata seorang siswa, semakin besar kemungkinan ia terampil berbahasa. Sehingga semakin tinggi penguasaan kosakata siswa akan semakin terampil dalam menulis. Sebaliknya, semakin rendah kosakata yang dimiliki siswa akan semakin rendah kemampuan menulis siswa.

Penguasaan kosakata siswa berbedabeda antara siswa yang satu dengan yang lainnya. Siswa yang mampu menguasai kosakata yang cukup biasanya akan lebih terampil dalam menulis. Sebaliknya siswa yang kurang dalam penguasaan kosakata akan lebih sulit dalam menulis khusunya menulis eksposisi. Pada kenyataannya, masih banyak siswa yang kurang mampu dalam menguasai kosakata bahasa Indonesia dengan baik. Sehingga banyak terjadi kesalahan dalam penulisan, pengucapan dan pemaknaan. Kurangnya penguasaan kosakata pada siswa disebabkan karena siswa tidak ada motivasi dalam belajar Bahasa selain itu lingkungan juga mempengaruhi penguasaan kosakata pada siswa. Oleh karena itu, guru sebagai pendidik perlu memberikan penguatan mengenai kata yang tepat untuk digunakan pada saat berkomunikasi dan memberikan pembelajaran yang mampu mendukung penguasaan kosakata siswa.

Subjek penelitian siswa kelas XI di SMA Negeri 03 Kota Bengkulu. rumusan 
masalah penelitian ini adalah sebagai berikiut ini. Pertama, Bagaimanakah Penguasaan Kosakata Siswa Kelas XI SMA Negeri 03 Kota Bengkulu. Kedua, Bagaimanakah Keterampilan Menulis Eksposisi Siswa Kelas XI SMA Negeri 03 Kota Bengkulu. Ketiga, Bagaimanakah korelasi Penguasaan Kosakata Dengan Keterampilan Menulis Eksposisi Siswa Kelas XI SMA Negeri 03 Kota Bengkulu. Sesuai dengan perumusan masalah, tujuan penelitian ini. Pertama, mendeskripsikan Penguasaan Kosakata Siswa Kelas XI SMA Negeri 03 Kota Bengkulu. Kedua, mendeskripsikan Keterampilan Menulis Eksposisi Siswa Kelas XI SMA Negeri 03 Kota Bengkulu. Ketiga, mendeskripsikan Korelasi Penguasaan Kosakata Dengan Keterampilan Menulis Eksposisi Siswa Kelas XI SMA Negeri 03 Kota Bengkulu. Jenis penelitian kuantitatif dengan metode deskriptif. Populasi dalam penelitian ini adalah 333 orang yang tersebar dalam sepuluh kelas. Sampel penelitian ini adalah kelas XI dengan jumlah 42 orang. Data penelitian ini diperoleh melalui tes objektif untuk penguasaan kosakata dan tes unjuk kerja untuk kemampuan menulis eksposisi.

Berdasarkan uraian di atas penulis bermaksud untuk melakukan penelitian yang berjudul" Korelasi Penguasaan Kosakata Dengan Keterampilan Menulis Eksposisi Siswa Kelas XI SMA Negeri 03 Kota Bengkulu”.

\section{Metode Penelitian}

Jenis penelitian yang akan dilaksanakan dalam penelitian ini adalah penelitian kuantitatif dengan menggunakan metode deskriptif. Penelitian kuantitatif adalah penelitian yang datanya diolah menggunakan angka, mulai dari pengumpulan data, penafsiran data, dan penampilan hasilnya. Metode yang digunakan dalam penelitian ini adalah metode deskripstif.

Metode deskripstif adalah suatu metode dalam meneliti suatu sekelompok manusia, suatu objek, suatu set kondisi, suatu system pemikiran ataupun suatu kelas peristiwa pada masa sekarang (Nazir, 1983:63). Metode deskriptif bertujuan untuk membuat deskripsi, gambaran atau lukisan secara sistematis, faktual dan akurat mengenai fakta-fakta serta hubungan antarfenomena yang diselidiki. Metode deskriptif dalam penelitian digunakan untuk mendeskripsikan korelasi penguasaan kosakata dengan keterampilan menulis eksposisi sisiwa kelas XI SMA Negeri 03 Kota Bengkulu..

\section{Hasil dan Pembahasan}

\section{Pemahaman Kosakata Siswa Kelas XI SMA Negeri 03 Kota Bengkulu}

Hasil penelitian dan analisis data menunjukan bahwa pemahaman Kosakata Siswa Kelas XI SMA Negeri 03 Kota Bengkulu terbagi atas lima kualifikasi yaitu baik sekali, baik, lebih dari cukup, cukup dan hampir cukup. Nilai rata-rata pemahaman kosakata siswa berada pada kualifikasi lebih dari cukup $(75,95 \%)$ berada pada rentang 66,75\%.

Keterampilan berbahasa membutuhkan penguasaan dan pemahaman kosakata yang cukup, Tarigan (1993:2) kualitas keterampilan berbahasa jelas tergantung kepada kuantitas dan kualitas kosakata yang dimilikinya. Semakin kaya kosakata semakin terampil siswa dalam berbahasa. (Chaer, 2007:6-7) menyatakan definisi kosakata yaitu. Pertama, semua kata yang terdapat dalam suatu bahasa. Kedua, kata-kata yang dikuasai seseorang atau sekelompok orang dari lingkungan yang sama. Ketiga, kata-kata atau istilah yang digunakan dalam satu bidang kegiatan atau ilmu pengetahuan. Keempat, sejumlah kata dari suatu bahasa yang disusun secara alfabetis beserta dengan jumlah penjelasan maknanya, layknya sebagai sebuah kamus. Kelima, semua morfem yang ada dalam suatu bahasa.

Setelah diteliti, pemahaman Kosakata Siswa Kelas XI SMA Negeri 03 Kota Bengkulu dengan rata-rata 75,95\% 
Volume 1, Nomor 2, Juli 2019

ISSN 2655-3031 (P), 2655-7851 (O)

berada di atas KKM yang telah ditetapkan sekolah yaitu 70\%. Dengan demikian dapat dinyatakan bahwa pemahaman kosakata siswa tergolong lebih dari cukup.

\section{Pemahaman Kosakata Siswa Kelas XI SMA Negeri 03 Kota Bengkulu untuk indikator Sinonim}

Sinonim adalah kelompok kata yang berbeda bentuk, namun mengandung makna yang sama. Usman (1979:80) sinonim adalah kata-kata yang berbeda bentuk tetapi bermakna sama. Latihan sinonim merupakan salah satu cara mengetahui pemahaman kosakata siswa.

Hasil penelitian dan analisis data menunjukkan bahwa Pemahaman Kosakata Siswa Kelas XI SMA Negeri 03 Kota Bengkulu untuk indikator sinonim berada pada kualifikasi sempurna, baik, cukup dan kurang dengan nilai rata-rata berada pada kualifikasi lebih dari cukup $(70,73 \%)$ pada rentangan $66-75 \%$.

\section{Pemahaman kosakata Kosakata Siswa Kelas XI SMA Negeri 03 Kota Bengkulu untuk Indikator Antonim}

Antonim adalah hubungan pertentangan makna atau kebalikan makna kata antara yang satu dengan yang lainnya atau nama lain untuk benda lain. Lyons (Dalam Manaf, 2008:102) menyatakan bahwa antonim adalah hubungan pertentangan makna atau kebalikan makna kata yang satu dengan makna kata yang lain yang mengandung perbedaan tingkat. Latihan antonim merupakan salah satu cara untuk mengetahui pemahaman kosakata siswa.

Hasil penelitian dan analisis data menunjukkan bahwa pemahaman Kosakata Siswa Kelas XI SMA Negeri 03 Kota Bengkulu untuk indikator antonim berada pada kualifikasi sempurna, baik, lebih dari cukup, hampir cukup dan kurang dengan nilai rata-rata pada kualifikasi baik $(78,04 \%)$ pada rentangan $76-85 \%$.
Pemahaman Kosakata Siswa Kelas XI SMA Negeri 03 Kota Bengkulu untuk Indikator Makna Kata

Munaf (2008:56) menyatakan bahwa makna kata adalah makna satuan bahasa sebagaimana yang diberikan atau yang diketahui oleh orang awam bersifat umum dan kurang akurat. Untuk mengukur pemahaman kosakata siswa guru dapat memberikan latihan makna kata.

Hasil penelitian dan analisis data menunjukkan bahwa pemahaman Kosakata Siswa Kelas XI SMA Negeri 03 Kota Bengkulu untuk indikator makna kata berada pada kualifikasi sempurna, baik sekali, lebih dari cukup, cukup, hampir cukup dan kurang dengan nilai rata-rata pada kualifikasi baik $(78,04 \%)$ pada rentangan $76-85 \%$.

\section{Kemampuan Menulis Eksposisi Siswa Kelas XI SMA N 03 Kota Bengkulu}

Berdasarkan analisis data yang diperoleh dapat disimpulkan bahwa kemampuan siswa dalam menulis rangkuman dikelompokan menjadi delapan kategori, yaitu baik sekali (BS), baik (B), lebih dari cukup (LDC), cukup (C), hampir cukup (HC), kurang (K), kurang sekali (KS), dan buruk (BR). Nilai rata-rata yang diperoleh siswa berada pada kualifikasi hampir cukup, yaitu 54,88 dengan rentangan nilai $46-55 \%$. Jika dibandingkan dengan KKM (78\%) mata pelajaran Bahasa dan Sastra Indonesia di SMA Negeri 03 Kota Bengkulu dapat diketahui bahwa kemampuan siswa dalam menulis eksposisi tidak memenuhi KKM (78\%).

Kemampuan Menulis Eksposisi Siswa Kelas XI SMA N 03 Kota Bengkulu Berdasarkan Indikator Ketepatan Isi dengan Tulisan Asli

Berdasarkan analisis data yang diperoleh dapat diketahui bahwa kemampuan Menulis Eksposisi Siswa Kelas XI SMA N 03 Kota Bengkulu pada indikator ketepatan isi karangan adalah 45,23 dan berada pada kualifikasi kurang. 
Dilihat dari ketiga indikator yang dijadikan penilaian dalam penelitian ini, indikator ketepatan isi karangan merupakan indikator yang kurang dikuasai siswa dalam menulis eksposisi. Siswa cenderung menulis isi karangan tidak menjelaskan pokok masalah yang telah dipilih, informasi yang dipaparkan tidak jelas dan memengaruhi perasaan dan sikap pembaca.

Kemampuan Menulis Eksposisi Siswa Kelas XI SMA N 03 Kota Bengkulu Berdasarkan Indikator Ketepatan penyampaian gagasan

Berdasarkan analisis data yang diperoleh dapat diketahui bahwa kemampuan menulis Eksposisi Siswa Kelas XI SMA N 03 Kota Bengkulu berdasarkan indikator ketepatan penyampaian gagasan adalah 40,95 dan berada pada kualifikasi kurang.

Dilihat dari ketiga indikator yang dijadikan penilaian dalam penelitian ini, indikator ketepatan penyampaian gagasan merupakan indikator yang masih kurang dikuasai siswa dalam menulis eksposisi. Secara umum siswa belum mampu menyusun Pendapat atau gagasan yang dikemukakan runtut, sesuai tema, tetapi pokok-pokok pikiran tidak diungkapkan dan dikembangkan dengan jelas, dan hubungan antarbagian tidak kohesif.

Kemampuan Menulis Eksposisi Siswa Kelas XI SMA N 03 Kota Bengkulu Berdasarkan Ketepatan Penggunaan Diksi dan EBI
Volume 1, Nomor 2, Juli 2019

ISSN 2655-3031 (P), 2655-7851 (O)

Berdasarkan analisis data yang diperoleh dapat diketahui bahwa kemampuan menulis Eksposisi Siswa Kelas XI SMA N 03 Kota Bengkulu dilihat dari indikator ketepatan diksi dan EBI adalah 76,19 dan berada pada kualifikasi baik.

Siswa sudah mampu menggunakan diksi dan EBI dengan tepat. Diksi yang digunakan sudah sesuai dengan situasi dan dapat dimengerti dan Informasi atau gagasan yang disajikan jelas, menggunakan kalimat efektif, pemakaiaan EYD tepat, diksi tepat, dan berupaya memperlihatkan perincian tentang objek yang ditulis. Hal tersebut dibuktikan dengan nilai rata-rata kemampuan menulis rangkuman berdasarkan indikator tersebut berada pada kualifikasi baik.

\section{Korelasi Kemampuan Penguasaan Kosakata dengan Kemampuan Menulis Eksposisi Kelas XI SMA N 03 Kota Bengkulu}

Hubungan antara kemampuan penguasaan kosa kata dengan kemampuan menulis eksposisi siswa kelas XI SMA N 03 Kota Bengkulu dicari dengan menggunakan rumus korelasi product moment. Data nilai kemampuan penguasaan kosakata dimasukan ke dalam variabel $\mathrm{X}$ dan data kemampuan menulis eksposisi dimasukan ke dalam variabel $Y$.

$$
\begin{aligned}
\mathrm{r}= & \frac{n \sum X Y-\left(\sum X\right)\left(\sum Y\right)}{\sqrt{\left\{n \sum X^{2}-\left(\sum X\right)^{2}\right\}\left\{n \sum Y^{2}-\left(\sum Y\right)^{2}\right\}}} \\
= & \frac{(42 \times 131185,4)-(2308,7)(2225,3)}{\sqrt{\left\{42 \times 131958,1-(2308,7)^{2}\right\}\left\{42 \times 140599,2-(2225,3)^{2}\right\}}} \\
= & \sqrt{\{5509786,8-5137550,11}
\end{aligned}
$$


Berdasarkan nilai $\mathrm{r}$ yang diperoleh, diketahui bahwa nilai korelasi kedua variabel adalah 0,82. Untuk menafsirkan keberartian hubungan antara kedua variabel, setelah nilai koefisien korelasi diperoleh, kemudian dilanjutkan dengan menguji keberartian hipotesis dengan menggunakan rumus $\mathrm{t}$ berikut ini.

$$
\begin{aligned}
& r \frac{\sqrt{n-2}}{\sqrt{1-r^{2}}} \\
= & 0,82 \frac{\sqrt{40}}{\sqrt{1-(0,82)^{2}}} \\
= & \frac{6,32}{0,57} \times 0,82 \\
= & 9,06
\end{aligned}
$$

Dari hasil pengujian hipotesis dapat disimpulkan bahwa terdapat hubungan antara kemampuan penguasasan kosakata dengan kemampuan menulis eksposisi siswa kelas XI SMA N 03 Kota Bengkulu pada taraf signifikan 95\% dengan derajat kebebasan n-2. Dengan demikian, H0 ditolak sedangkan $\mathrm{H} 1$ diterima karena hasil pengujian membuktikan bahwa $\mathrm{t}$ hitung lebih besar dari t tabel yaitu 9,06 lebih besar dari 1,68. Untuk lebih jelasnya dapat dilihat pada tabel berikut.

Tabel 17 Uji Hipotesis

\begin{tabular}{|l|l|l|l|}
\hline$R$ & thitung & N-2 & $\begin{array}{l}\text { Ttabel } \\
\text { P95\% }\end{array}$ \\
\hline 0.82 & 9.06 & 40 & 1.68 \\
\hline
\end{tabular}

\section{Simpulan}

Berdasarkan deskripsi data, analisis data, dan pembahasan mengenai hubungan kemampuan penguasaan kosakata dengan kemampuan menulis eksposisi siswa kelas XI SMA N 03 Kota Bengkulu dapat disimpulkan tiga hal sebagai berikut.
Pertama, kemampuan penguasaan kosakata siswa kelas XI SMA N 03 Kota Bengkulu berada pada kualifikasi hampir cukup $(54,96)$. Kedua, kemampuan menulis eksposisi siswa kelas XI SMA N 03 Kota Bengkulu berada pada kualifikasi hampir cukup $(54,88)$. Ketiga, terdapat hubungan yang signifikan antara kemampuan penguasaan kosakata dengan kemampuan menulis eksposisi siswa kelas XI SMA N 03 Kota Bengkulu.

Berdasarkan hasil penelitian dan simpulan, dapat diberikan saran-saran sebagai berikut. Pertama, guru Bahasa dan Sastra Indonesia di SMA N 03 Kota Bengkulu diharapkan lebih meningkatkan kemampuan penguasaan kosakata siswa dengan mengadakan latihan intensif dan hendaknya dilakukan secara terencana serta terprogram. Kedua, untuk meningkatkan kemampuan penguasaan kosakata dan kemampuan menulis eksposisi siswa di kelas XI SMA N 03 Kota Bengkulu hendaknya bukan semata-mata merupakan tanggung jawab guru Bahasa Indonesia, tetapi juga jajaran pimpinan sekolah dengan menyediakan sarana dan prasarana serta yang dapat mengembangkan bakat dan minat siswa dalam menulis. Ketiga, siswa diharapkan untuk lebih menyadari pentingnya menguasai kosakata, karena berhubungan dengan keterampilan menulis. Keempat, untuk meningkatkan kemampuan menulis eksposisi maka terlebih dahulu ditingkatkan kemampuan penguasaan kosakata dengan baik.

\section{Daftar Pustaka}

Abdurrahman dan Ellya Ratna. (2003). "Evaluasi Pembelajaran Bahasa dan Sastra Indonesia". (Buku Ajar). Padang: Jurusan Bahasa dan Sastra Indonesia FBSS UNP. 
Arikunto, Suharsimi. (2006). Prosedur Penelitian: Suatu Pendekatan Praktik Edisi Revisi VI. Jakarta: Rineka Cipta.

Anonim. (2011). Metode Deskriptif. http://idtesis.com/metode-deskriptif/. Diunduh Pada Tanggal23/05/12.

Arifin dan Tasai. (2008). Cermat Berbahasa Indonesia. Jakarta: Akademika Pressindo.

Chaer, Abdul. 2007. Leksikologi dan Leksikografi Indonesia. Jakarta: Rineka Cipta.

Erfiati. 2009. Peningkatan Kemampuan Menulis Karangan Eksposisi dengan Pendekatan Kontekstual Pembelajaran Berbasis Masalah Di SMA Negeri 1 Curup Timur. UNIB.

Gani, Erizal. 1999. Pembinaan Kemampuan Menulis di Perguruan Tinggi (Bahan Ajar). Padang: FBSS IKIP.

Gie, The Liang. 1992. Pengantar Dunia Karang Mengarang. Liberty Yogyakarta: Yogyakarta.

Keraf, Gorys. 2002. Diksi dan Gaya Bahasa. Jakarta: PT Gramedia Pustaka Utama.

Keraf, Gorys. 1994. Komposisi. Ende-Flores: Nusa Indah.

Keraf, Gorys. 1995. Eksposisi. Jakarta: PT Grasindo.

Keraf, Gorys. 1982. Eksposisi dan Deskripsi. Jakarta: Nusa Indah.

Keraf, Gorys. 2005. Diksi dan Gaya Bahasa: Komposisi dan Lanjutan I Edisi yang Diperbaharuhi. Jakarta: Gramedia.

Manaf, Ngusman Abdul. 2008. Semantik Teori dan Terapannya dalam Bahasa Indonesia. Padang: Sukabina Offset.

Nursaid. 2006. Kurikulum 2006 Bahasa Indonesia. Padang: FBSS UNP.

Pateda, Mansoer. 1995. Kosakata dan Pengajarannya. Ende Flores: Nusa Enda.

Tarigan, Henry Guntur. 1993. Pengajaran Kosakata. Bandung: Angkasa.

Usman, Amir Hakim.1979. Pengantar Ilmu Kosakata (Leksikologi). Padang: FKSS IKIP Padang. 